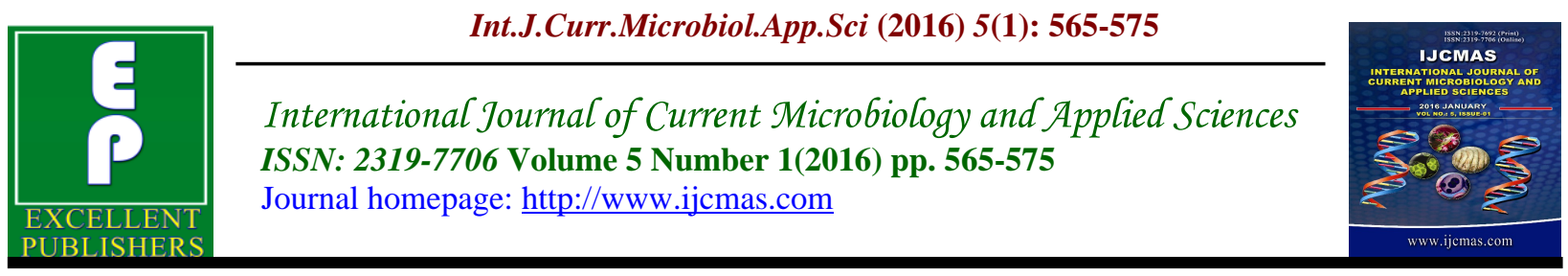

Original Research Article

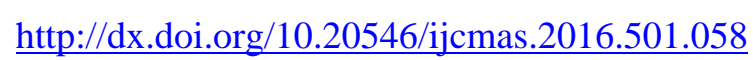

\title{
Screening, Localization and Activity of Mushroom Tyrosinase from Various Developmental Growth Phases of Pleurotus florida
}

\author{
Anjana Sharma*, Juhi Sharma and Pooja Thakrele \\ Department of P. G. Studies and Research in Biological Science, Rani Durgavati University, \\ Pachpedi, Jabalpur 482001, Madhya Pradesh, India \\ *Corresponding author
}

\begin{tabular}{|c|c|}
\hline & A B S T R A C T \\
\hline $\begin{array}{l}\text { Ke y w o r d s } \\
\text { Pleurotus florida, } \\
\text { Mushroom } \\
\text { cultivation, } \\
\text { Tyrosinase, } \\
\text { Growth stages, } \\
\text { Localization } \\
\text { Article Info }\end{array}$ & $\begin{array}{l}\text { The present work is designed for the utilization of agricultural waste for } \\
\text { mushroom production and extraction of tyrosinase through-out its } \\
\text { developmental growth phases. Various edible mushrooms were screened for } \\
\text { tyrosinase activity resulting highest activity in Pleurotus } \\
\text { spectrophotometrically. The results also showed that Mushroom could be } \\
\text { cultivated using wheat grains and wheat straw. Tyrosinase was observed } \\
\text { throughout the growth phases from mycelium to mature stages revealing that } \\
\text { maximum tyrosinase activity and highest protein content was observed in }\end{array}$ \\
\hline $\begin{array}{l}\text { Accepted: } \\
25 \text { December } 2015 \\
\text { Available Online: } \\
\text { January } 2016\end{array}$ & $\begin{array}{l}\text { premature stage. Result for morphological parts evaluation of mushroom } \\
\text { showed that maximum tyrosinase was present in stalk region of mushroom. } \\
\text { This is first report about the screening of tyrosinase from both } \\
\text { morphological parts and developmental phases of mushroom. }\end{array}$ \\
\hline
\end{tabular}

\section{Introduction}

Tyrosinases are widely distributed in nature; they are found both in prokaryotic as well as in eukaryotic microbes, in mammals and plants. These enzymes are known as type 3 copper proteins having a diamagnetic spincoupled copper pair in the active centre. The hydroxylation ability of the enzyme is also referred to cresolase or monophenolase activity (EC 1.14.18.1), and the oxidation ability to catecholase or diphenolase activity (EC 1.10.3.1). Monophenolase activity of Tyrosinases is known to be the initial ratedetermining reaction.
Tyrosinases are involved in several biological functions. Presently there is an increasing interest in using tyrosinases in industrial applications. Traditionally tyrosinases have been exploited in plantderived food products, e.g. tea, coffee, raisins and cocoa, where they produce distinct organoleptic properties. However, in fruits and vegetables, tyrosinases are also related to undesired browning reactions where upon, methods for controlling tyrosinase activity are constantly searched in the food industry Majidi and Aksöz, 2013. 
Furthermore, tyrosinas has industrial applications such as its use as biosensor for oxygen and phenols, the stereospecific synthesis of quinones, phenols and phenolic polymers, and in the bioremediation of wastewater containing phenolic pollutants (Fenoll et al. 2002). Thus the present work was aimed to study tyrosinase from various edible mushroom.

The limit of these applications remains in the fact that native fungal tyrosinase are generally intracellular and produced in low quantity (Halaouli et al., 2006). The exploitation of tyrosinase from various parts of mushroom is considered, for Pleurotus florida.

Mushrooms are highly nutritive, low-calorie food with good quality proteins, vitamins and minerals. Mushrooms are an important natural source of foods and medicines. Traditional originals knew the medicinal importance of edible and wild mushrooms and these are now being screened for their bioactivity in various ailments. Mushroom represents a major and untapped source of potent new pharmaceutical products. They are also known to possess promising antioxidative, cardiovascular, hypercholesterolemia, antimicrobial, hepatoprotective and anticancer effects. The present paper aimed to discuss on mushroom cultivation as well as importance for tyrosinase extraction. Pleurotus mushroom cultivation is very popular and next to Agaricus bisporus mushroom in India in popularity and consumption. This together form bulk of edible mushrooms produced in country. In India Pleurotus has been successfully cultivated on banana pseudostem and paddy straw. Rice straw, wheat straw, ragi straw, hulled maize cab, waste paper were tried in different studies (Khatun et al., 2012). Use of costly substrate for growing oyster mushroom increases their cost of production. So there was need to search for certain alternative materials which should be available in sufficient quantity at relatively cheaper price. This paper thus reports the cultivation of Pleurotus that has been reported to grow readily on a number of non-conventional substrates.

In the Agaricus strain, the epidermis, cap flesh, gill, and stalk tissue showed similar enzyme after isoelectric focusing, but the distribution of staining intensity appeared different for each type tissue. Younger developmental stages of Agaricus mushrooms showed a different enzyme profile than older ones. Mature mushrooms cut at the stipe showed a different distribution of enzyme staining than those not cut at the stipe, indicating possible activation of latent enzyme or new synthesis of specific tyrosinase isoenzymes. Till date as per our knowledge no such study is done on Pleurotus florida. The present study is the fore most study to locate tyrosinase in various morphological parts of Pleurotus.

These measurements have shown the difficulty in comparing the enzyme activity of different growth phases and thus in obtaining reproducible results in the comparative assay of the enzyme activity of mushroom (Boiret et al., 1985). Moreover, assays performed on a unique specimen of a given mushroom parts result on considerable differences in tyrosinase activity depending on the morphological part under study. Therefore we initiated a systematic approach of the enzyme's activity distribution in various morphological and different growth stages.

Much less information is available on the activity, location of tyrosinase in developing mushrooms. That tyrosinase activity is present in the pileus (cap) and stipe (stalk) of mushrooms at three developmental stages, it was reported that the skin 
contained more enzyme than the flesh based on either a fresh weight or on a protein basis (Ingebrigtsen et al., 1989).

Thus the present paper was designed to study the activity of tyrosinase in various edible mushrooms, cultivation of the mushroom with maximum tyrosinase activity using agro waste, screening of various growth phases of mushroom for tyrosinase activity and localization of tyrosinase in morphological parts of the mushroom.

\section{Materials and Methods}

\section{Mushroom Sources}

Two edible mushrooms namely Agaricus bisporus and Pleurotus florida were purchased from food park Industrial area, Maneri, Mandla, M.P. While milky mushroom was purchased from mushroom farms, INA market, Delhi. Starting culture of Pleurotus florida was purchased from directorate of mushroom research (Solan).

Primary Screening of Mushroom for Tyrosinase Activity (Boiret et al., 1985)

Qualitative imaging of mushroom was done to screen them for tyrosinase activity. The mushroom was cut into two longitudinal halves and immediately solution of $0.002 \mathrm{M}$ of L-DOPA in 0.1MTrisHCl buffer ( $\mathrm{pH} 7.0)$ containing $0.1 \mathrm{M}$ Sodium floride, $\mathrm{pH} 7.0$ was sprayed in a homogenous manner, on its cross section surface and the appearance of red color along with time was recorded.

Secondary Screening of Mushroom for Tyrosinase Activity

Preparation of Enzyme Extracts (Zaidi et al., 2014)

The sliced mushrooms were homogenized by warming blender. Enzyme extraction was prepared with $500 \square \mathrm{mL}$ of cold $100 \square \mathrm{mM}$ phosphate buffer ( $\mathrm{pH} \mathrm{5.8)}$ ) for $300 \square \mathrm{g}$ of mushroom. The supernatant was used as a source of enzyme.

\section{Determination of Tyrosinase Activity}

The method of Duckworth and Coleman, 1970, was followed to determine the tyrosinase activity. To10 $\mathrm{ml}$ phosphate buffer $(50 \mathrm{~m}$ in $\mathrm{pH} 6.5)$ and $10 \mathrm{ml}$ $1 \mathrm{mMtyrosine}$ was mixed and oxygenated by bubbling $99.9 \%$ pure oxygen. (Fig.1) 0.1 $\mathrm{ml}$ enzyme extract was added to a cuvette containing $2.90 \mathrm{ml}$ of above prepared solution and was immediately mixed and the formation of dopachrome at $280 \mathrm{~nm}$ was recorded. One unit of enzyme was defined as 0.001 per min increase in absorbance at $280 \mathrm{~nm}$ of reaction mixture under standard assay conditions.

\section{Determination of Protein Content (Lowry et al, 1951)}

To $0.1 \mathrm{ml}$ of sample, $2.5 \mathrm{ml}$ of alkaline copper sulphate reagent was added, mixed well and allowed to stand at room temperature for $10 \mathrm{~min}$., then $0.25 \mathrm{ml}$ of $1 \square 1$ double diluted Folin-Ciocalteu's phenol reagent was added and after $30 \mathrm{~min}$ of incubation at room temperature, absorbance was measured at $660 \mathrm{~nm}$. The protein content was calculated from a standard curve prepared with bovine serum albumin.

\section{Determination of Specific Activity}

Specific activity (EU/ mg) was determined by dividing total activity $(\mathrm{EU} / \mathrm{ml})$ with total protein concentration $(\mathrm{mg} / \mathrm{ml})$.

\section{Mushroom Production}

\section{Preparation of Mycelium Culture (Ramkumar et al., 2011)}

Potato dextrose agar medium was prepared and Starting culture was procured from 
Solan was used to inoculate PDA plates. Forceps was disinfected with hypochlorite for $5 \mathrm{~min}$ and rinsed for 3 times in distilled water were placed on Potato Dextrose Agar in petridish and incubated at $25^{\circ} \mathrm{C}$ for 10 days.

\section{Preparation of Spawn Culture (Ahlwat and Tiwari, 2007)}

Starting culture of Pleurotus florida was raised by following the method of Ahlwat and Tiwari, 2007. Small pieces of tissue mycelium (2mm) of Pleurotus florida were inoculated in plates of potato dextrose agar media and were incubated at $22^{\circ} \mathrm{C}$ for $4-5$ days. Small mycelium bearing portion was further used as inoculums.

Spawn Production (Royse and SanchezVazquez, 2013)

Wheat Grains were used as a substrate for Pleurotus florida. Substrate was soaked in $0.1 \%$ carbendazine solution overnight. The solution was drained completely and dried under shade. At 50\% moisture level the substrate was mixed thoroughly with both artificial and precipitated $\mathrm{CaCO}_{3}$, to $3 / 4$ capacities of $500 \mathrm{ml}$ glass bottles. Then the mouth of bottles was tightly plugged with non absorbent cotton and sterilized at $15 \mathrm{lbs}$ pressure for $2 \mathrm{hrs}$. The substrate was allowed to cool and inoculated with fungal stalk culture aseptically and incubated at $25^{\circ} \mathrm{C}$ for 15 days. $2 \mathrm{~mm}$ mycelium were added to spawn with $\mathrm{CaCO}_{3}(3 \%)$.

Extraction of Tyrosinase from each Growth Phase of Mushroom

\section{Preparation of Substrate (Ahlwat and Tiwari, 2007)}

The substrate (wheat straw) 150gm were chopped, soaked in water overnight and drained to remove excess water. $2 \%$ Urea and calcium carbonate were then mixed (w/w), and autoclaved at $15 \mathrm{psi}, 121^{\mathrm{O}} \mathrm{C}$ for 90 minutes.

\section{Preparation of Spent Substrate Bags} (Ahlwat and Tiwari, 2007)

$250 \mathrm{gm}$ of Wheat straw was used as substrate. Substrate was then filled in thin polythene bags and soaked in water tank for $12 \mathrm{hrs}$ and then bags were removed from water to drain excess of water, calcium carbonate $(3 \%)$ were then mixed $(\mathrm{w} / \mathrm{w})$, and substrate was then autoclaved for $2 \mathrm{hrs}$ at $121^{\circ} \mathrm{C}$. After autoclaving, bags were opened and straw was spread on table for $5 \mathrm{hrs}$ and then allowed to cool. Then $250 \mathrm{gm}$ of substrate was put in bags of $12 \times 18 \mathrm{~cm}$ size, sterilized by autoclaving for $2 \mathrm{hrs}$ at $121^{\circ} \mathrm{C}$, and was inoculated with $5 \%$ spawn of Pleurotus florida.

\section{Harvesting of Mushroom at Different Growth Phase (Ahlwat and Tiwari, 2007)}

After proper sterilization, inoculation, incubation, mycelium maturation and pigmentation of the tip of bump, all the packets were opened from the top side and soaked in water for 15-20 min. Then the packets were placed separately on the cemented floor of culture house.

The temperature, relative humidity and light were maintained at $18-22{ }^{\circ} \mathrm{C}, 60-70 \%$ and 10-20 lux, respectively. Sufficient water was applied and proper aeration was maintained in incubator to release $\mathrm{CO}_{2}$ and to supply of proper oxygen for primordial initiation and fruiting body development.

\section{Extraction of Enzyme at Different Growth Phase of Mushroom (Zaidi et al., 2014)}

At the end of each stage of development, crude enzyme from the fruiting body of 
mushroom was extracted tyrosinase activity was determined according to standard assay method.

\section{Results and Discussion}

\section{Screening of Mushroom for Tyrosinase Activity}

All the four mushrooms were kept under similar condition and were screened qualitatively for tyrosinase activity (Fig-1) quantity substantial tyrosinase activity was determined in two mushrooms (Table-1) they are Agaricus bisporus and Pleurotus florida significant enzyme activity was observed in these isolates; Agaricus bisporus (6.112 Unit/mg), and Pleurotus florida (7.74 Unit/mg) followed by Pleurotus dyjamore (5.8 Unit/mg) and Pleurotus oysterus (3.63 Unit/mg).

\section{Quantitative Screening of Mushroom Revealed Non-homogenous Distribution of Mushroom Tyrosinase}

Part of stem connecting cap revealed presence of tyrosinase in slightly more concentration. The distribution of tyrosinase activity seemed to be more homogenous in cap whereas other part showed even distribution of enzyme. The cap spin and lamellae are collected by pealing and scraping respectively. (Table2).

Stem region showed variation for the presence of tyrosinase with $9.0 \mathrm{Unit} / \mathrm{mg}, 7.1$ Unit/mg and $6.0 \mathrm{Unit} / \mathrm{mg}$ respectively.

The result shows that mean mycelium fresh weight was $0.033 \mathrm{gm}$ of mycelium produced using 3\% calcium carbonate. Mean mycelia extension was 0.161 cmof mycelium. Tyrosinase activity (Unit/mg protein) was maximum for mycelium is $0.68 \mathrm{Unit} / \mathrm{mg}$ protein (Table 3 ).
Assesment of Mushroom Production, Tyrosinase Activity and Calcium Content

Primordial formation occurred after 20 days of inoculation of spent bags with 8 units of $0.05 \mathrm{gm}$ each and $0.26 \%$ biological efficiency and 48.7 moisture content. It has $0.5 \mathrm{IU} / 3 \mathrm{gm}$ Tyrosinase activity and $2.13 \mathrm{mg} /$ 100 gm dry weight calcium.

Bud stage occurred after 21 days of primordial formation with 5 units of 1.31 gm each and $4.63 \%$ biological efficiency and 50.2 moisture content. It has $2.3 \mathrm{IU} / 3 \mathrm{gm}$ Tyrosinase activity and $5.2 \mathrm{mg} / 100$ gm dry weight calcium (Fig. 2)

Young stage occurred after 12days of bud stage with 3 units of $2.7 \mathrm{gm}$ each and $8.13 \%$ biological efficiency and 53 moisture content. It has $4.3 \mathrm{IU} / 3 \mathrm{gm}$ Tyrosinase activity and $8.9 \mathrm{mg} / 100 \mathrm{gm}$ dry weight calcium.

Premature stage occurred after 8 days of young stage with 3 units of $4.3 \mathrm{gm}$ each and $12.9 \%$ biological efficiency and 53.8 moisture content. It has $4.8 \mathrm{IU} / 3 \mathrm{gm}$ Tyrosinase activity and $12.5 \mathrm{mg} / 100$ gm dry weight calcium.

Mature stage occurred after 6 days of premature stage with 2 units of 5.2 gm each and $6.93 \%$ biological efficiency and 57.2 moisture content. It has $5.6 \mathrm{IU} / 3 \mathrm{gm}$ Tyrosinase activity and $18.1 \mathrm{mg} / 100$ gm dry weight calcium (Fig 3).

Mushrooms are appreciated, not only for texture and flavor but also for their chemical and nutritional characters (Manzi et al., 1999). Some recently isolated and identified compounds, originating from mushrooms, show other quite significant medical properties, such as immunomodulatory, cardiovascular, liver protective, anti-fibrotic, 
anti-inflammatory, anti-diabetic, anti-viral, and antimicrobial activities (Mata and Salmones, 2003).The success of the commercial mushroom cultivation is largely depending on the quality of components used for its production (Ramkumar et al., 2011) thus we tried to develop the substrate as agrowaste for cultivation of Pleurotus florida.

Tyrosinase (monophenol, 3-4 dihydroxy Lphenylalanine (L-DOPA): oxygen oxidoreductase, EC 1.14.18.1) is a bifunctional copper containing enzyme that uses molecular oxygen to catalyze the oxidation of mono - phenols to their corresponding o- diphenols (monophenolase activity) and their subsequent oxidation to $o$ quinones (catecholase activity) (Faria et al., 2007). The resulting highly reactive $o$ quinones auto-polymerize to form polyphenolic catechol melanins, which are an important constituent of humus and help in soil conditioning. Mushrooms are important source of this enzyme and many researchers are exploiting mushrooms for the production of Tyrosinase enzyme (Decker et al., 2000). It also play an important role in the conversion of phenolic compounds to organic derivatives and correspondingly to humus.

Enzyme and their application in different industrial sectors have gained importance during the present industrial age; the present study also exploited this function of tyrosinase (Ikehata and Nicell, 2000).

Results from the study have clearly shown that mushroom species used in the study contained considerable amount of tyrosinase which are vital in supplementing nutrition to mankind and could be used for various biotechnological applications

Table.1 Tyrosinase Activity of Mushroom

\begin{tabular}{ccccc}
\hline S.No. & Mushroom & $\begin{array}{c}\text { Total activity } \\
\text { (Units) }\end{array}$ & $\begin{array}{c}\text { Total protein } \\
\text { (mg) }\end{array}$ & $\begin{array}{c}\text { Specific activity } \\
\text { (U/mg) }\end{array}$ \\
\hline 1- & Agaricus bisporus & 30.56 & 5.01 & 6.112 \\
2- & Pleurotus florida & $\mathbf{3 8 . 5 7}$ & $\mathbf{4 . 9 8}$ & $\mathbf{7 . 7 4}$ \\
3- & Pleurotus dyjamore & 36.23 & 6.23 & 5.81 \\
4- & Pleurotus oysterus & 42.89 & 11.6 & 3.69 \\
\hline
\end{tabular}

Table.2 Tyrosinase Activity Measured in the Morphological Parts of Mushroom

\begin{tabular}{|c|c|c|c|c|c|}
\hline \multirow{2}{*}{ S.No. } & \multirow{2}{*}{$\begin{array}{c}\text { Parts of } \\
\text { mushroom }\end{array}$} & $\begin{array}{c}\text { Weight } \\
(\mathbf{g m})\end{array}$ & $\begin{array}{c}\text { Total activity } \\
(\mathbf{U n i t} / \mathbf{m g})\end{array}$ & $\begin{array}{c}\text { Total } \\
\text { protein } \\
(\mathbf{m g} / \mathbf{m l})\end{array}$ & $\begin{array}{c}\text { Specific } \\
\text { activity } \\
(\mathbf{U n i t} / \mathbf{m l})\end{array}$ \\
\hline \multirow{3}{*}{$\mathbf{1 -}$} & \multirow{3}{*}{ Stem } & 3.01 & 39.78 & 4.36 & 9.12 \\
\cline { 3 - 6 } & & 3.12 & 35.79 & 4.86 & 7.36 \\
\cline { 3 - 6 } & \multirow{2}{*}{$\mathbf{2 -}$} & 3.03 & 33.26 & 4.98 & 6.67 \\
\hline $\mathbf{3}$ & Cap & 3 & 28.01 & 3.84 & 7.29 \\
\hline $\mathbf{4 -}$ & Lamellae & 3.05 & 30.89 & 5.16 & 5.98 \\
\hline $\mathbf{5 -}$ & Skin & 2.89 & 27.85 & 4.87 & 5.71 \\
\hline
\end{tabular}


Table.3 Spawn Production of Pleurotus Florida

\begin{tabular}{|c|c|}
\hline Weight of flask (gm) & $\begin{array}{l}97.825 \\
95.216 \\
96.431 \\
\end{array}$ \\
\hline Dry weight of grains (gm & 82 \\
\hline Weight of grains (gm) & $\begin{array}{l}145.322 \\
147.591 \\
143.616\end{array}$ \\
\hline Dry weight basis $\mathrm{CaCo}_{3}$ (gm) & 2.46 \\
\hline Weight of mycelium (gm) & $\begin{array}{l}0.012 \\
0.053 \\
0.034\end{array}$ \\
\hline mean & $\mathbf{0 . 0 3 3}$ \\
\hline Height of mycelium (cm) & $\begin{array}{c}0.132 \\
0.21 \\
0.141\end{array}$ \\
\hline mean & 0.161 \\
\hline Tyrosinase Activity (Unit/mg) & $\begin{array}{l}0.32 \\
0.37 \\
0.38 \\
\end{array}$ \\
\hline Mean & 0.35 \\
\hline
\end{tabular}

Fig.1 Qualitative Imaging of mMushroom ( $\mathrm{A}=$ Pleurotus florida and $\mathrm{B}=$ Agaricus bisporus $)$ was Done to Screen it for Tyrosinase Activity
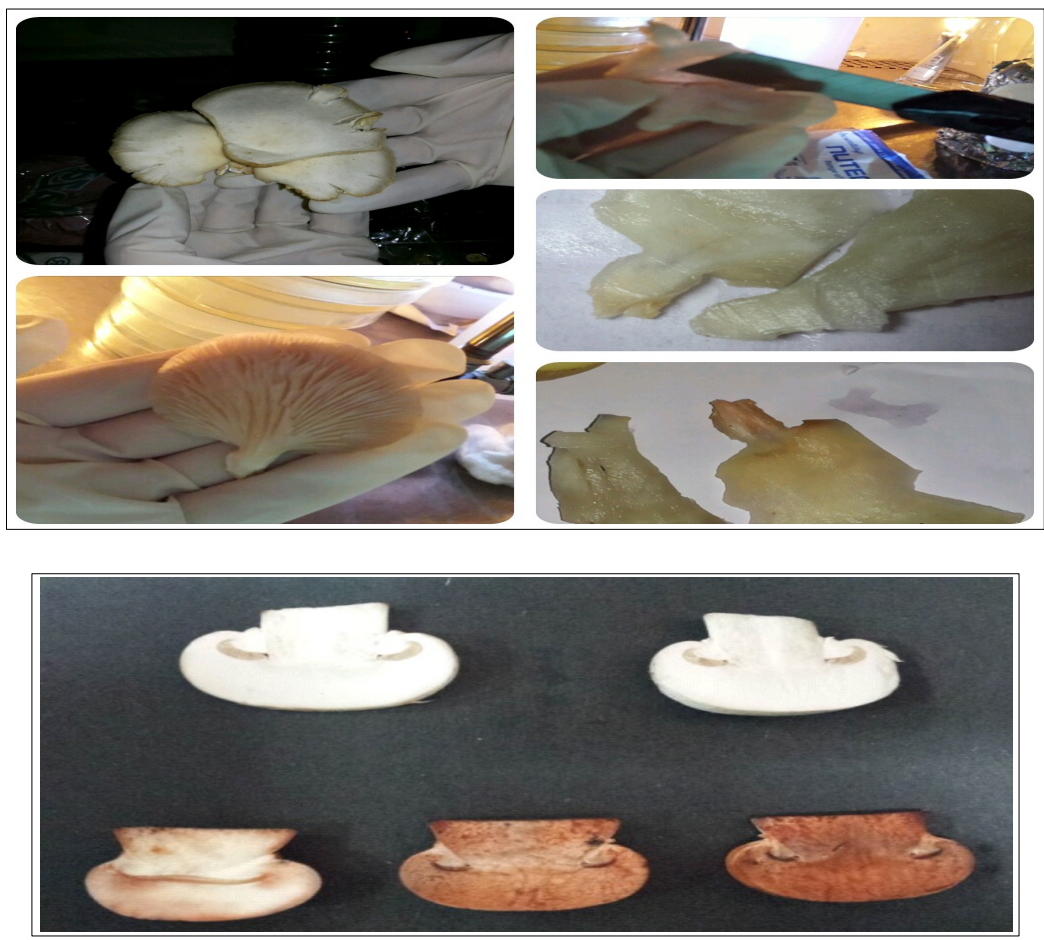

Fig 1.Qualitave imaging of mushroom (A= Pleurotus florida and B=Agaricus bisporus) was done to screen it fortyrosinase activity. The mushroom was cut in to two long itudinal halves and immediately solution L-DOPA in Tris HCl buffer containing Sodium floride, was sprayed in a homogenous manner, on its cross section surface and the appearance of red color was recorded. 
Fig.2 Different Growth Phases of Mushroom Production

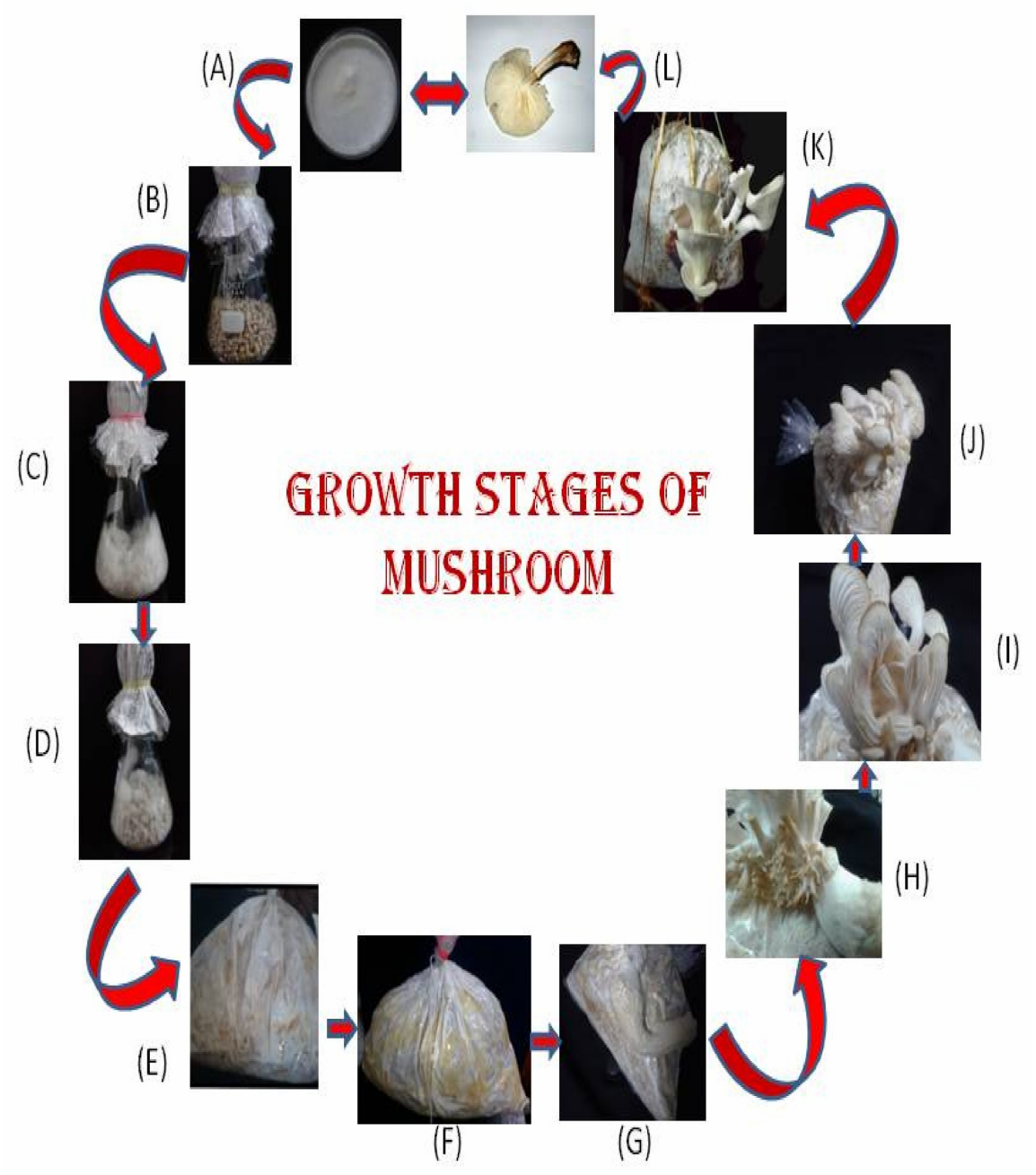

Fig 2 Different growth phases of mushroom production
A. Mycelium grown in potato dextrose agar medium
B. Wheat Grains used as substrate for spawn production
C. Spawn running
D. Mother Spawn used for inoculation of spent bag
E. Spent bag prepared from wheat straw
F. Spent bag with fully grown mycelium culture
G. Appearance of bud in spent bag
H. Appearance of mushroom bud
I. Mushroom in young stage
J. Mushroom in premature stage
K. Mushroom in mature stage
L. Fully grown mushroom 
Fig.3 Tyrosinase Activity (IU/3gm) and Biological Efficiency (g/150gm ) of Mushroom at Different Growth Stages

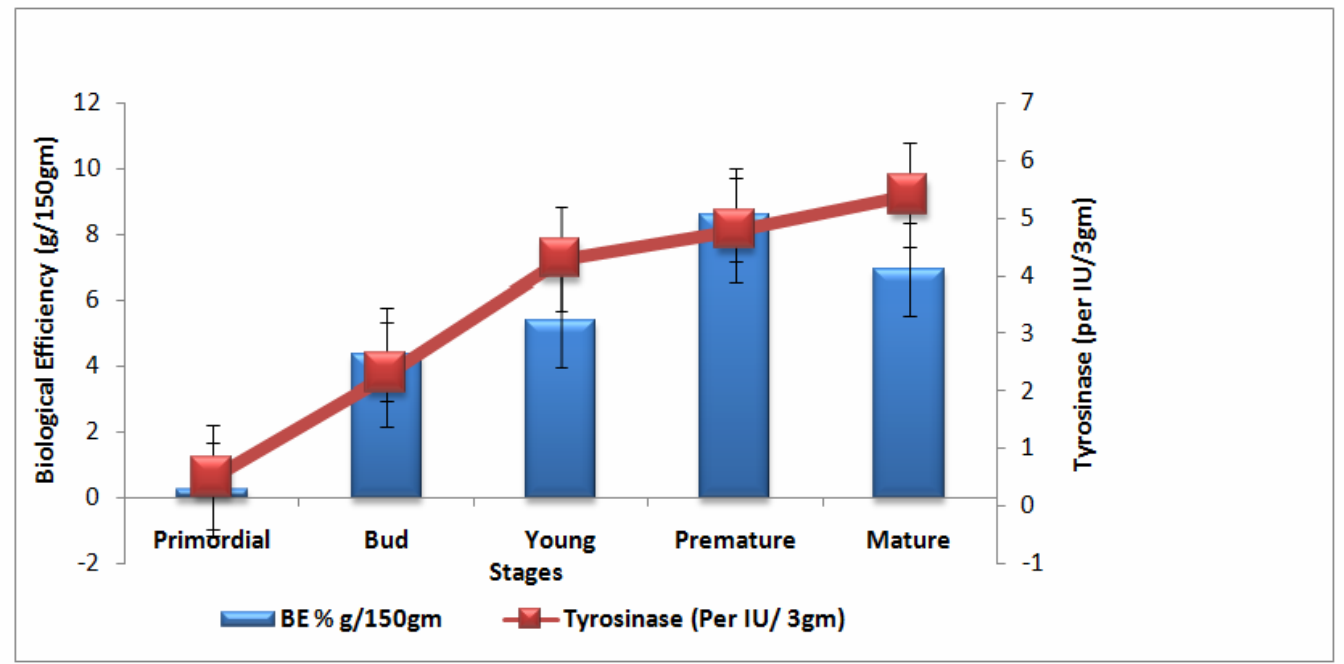

Mushroom Tyrosinase has been examined extensively with regard to physical and enzymatic characteristics. Many of these studies have used commercial enzymes which were not pure, uncharacterized, lacked all the enzymes present in growing mushrooms, and may have been derived from mixtures of mushrooms strains. In contrast, little information is available on the enzyme in mushrooms during development, post-harvest treatment, and storage. A few studies have been directed toward examining the enzyme during aging, in processed mushrooms, in post-harvest treatments, and in different strains of mushrooms. Even less information is available on the enzyme during specific development stages although tyrosinase was studied in the M8 strain of Agaricus, in the D649 and U3 Agaricus strain, in Agaricus bisporus, and in white Agaricus bisporus no such study is reported with Pleurotus. The objective of our study was to examine tyrosinase in different strains of Mushroom. We observed that Pleurotus has maximum enzyme activity. Distribution of tyrosinase appeared to change with development and activity of some tyrosinase appeared to decrease with development of the mushroom. This observation was in accordance with Adenipekun and Lawal 2012 who also reported the same. Deliberate damage to the mushrooms changes $t$ he distribution of enzyme activity compared to undamaged tissues. Maximum enzyme activity was primarily screened in stem of Pleurotus which was confirmed by secondary screening with $9.12 \mathrm{U} / \mathrm{mg}$ protein. Similarly highest enzyme activity was observed in premature growth phases of Pleurotus which was in accordance with Royse and Sanchez-Vazquez, 2003 who also screened activity in various growth stages of Lentinus edodoes.

Reason for the above finding could be that during mushroom development many changes occur as the mushroom expands from small pins to the mature mushroom. Tyrosinase was monitored in several developmental stages selected by size and/or maturity. Results have shown that the various developmental stages contained different amounts of protein as well as different amounts of tyrosinase. The enzymes were present in all developmental 
stages but showed much less staining intensity in immature and mature mushrooms.

Pleurotus, second most used mushroom after Agaricus could be grown using agricultural waste. Tyrosinase, enzyme which has lots of biotechnological application could be successfully extracted from various morphological parts of Pleurotus florida throughout the developmental cycles of mushroom growth. Thus, this work shows the exploitation of wheat straw for cultivation of Pleurotus, which could be consecutively, used for extraction of tyrosinase.

\section{Acknowledgement}

Authors are thankful to Head, Department of P.G. Studies and Research in Biological Science, R.D. University, Jabalpur for providing Lab facilities and Directorate of Mushroom research Solan, Himachal Pradesh for providing starter culture of Pleurotus.

\section{References}

Adenipekun, C.O. and R. Lawal.2012. Uses of mushrooms in bioremediation: A review. Biotechnology and Molecular Biology.7(3).62-68.

Ahlawat, O.P. and Tiwari, R.P. 2007. Cultivation technology of Paddy Straw Mushroom. National Research Centre for Mushroom

Boiret, A., M. Marty and Deumii, M. 1985.Distribution of Activity of Tyrosinase in the Mushroom.Biochemical Education.13(2).

Boiret, N., 2005. Characterization of nonexpandedmesenchymal progenitor cells from normal adult human bone marrow. Experimental Hematology.
33 (2): 219-225.

Boiret, N., A, Marty, Deumie, M. 1985.Distribution of activity of tyrosinase in the mushroom. Chemical Education.13(2).

Decker, H., R. Dillinger and Tuczek, F. 2000. How does tyrosinase work? Recent insights from model chemistry and structural biology.Chemistry International.39.1591-1595.

Duckworth, H, W. and Colman, J.E. 1970.Physicochemical and kinetic properties of mushroom tyrosinase.Journal of biological Chemistry. 245: 1613-1625.

Faria, R.O., R.M. Vivian, A. Maria, A. Almeida, N. Krieger and Alexander, D.M. 2007.The Biotechnological Potential of Mushroom Tyrosinases Biotechnology of Mushroom Tyrosinases.Food Technology and Biotechnology.45 (3).287-294.

Fenoll, L.G., J. N. Rodr'1guez-López, F. Garc'1a-Molina, F. Garc'1a-Cánovas and Tudela, J. 2002. Michaelis constants of mushroom tyrosinase with respect tooxygen in the presence of monophenols and diphenols. The International Journal of Biochemistry and Cell Biology.34 (5) 332-336.

Flurkey, W.H. 1991. Identification of Tyrosinase in Mushrooms by Isoelectric Focusing. Journal Of Food Science. 56 (I). 93.

Halaouli, S., M. Asther, J.-C.Sigoillot, M. Hamdi and Lomascolo, A. 2006. Fungal tyrosinases: new prospects in molecularcharacteristics, bioengineering and biotechnological applications. The Society for Applied Microbiology, Journal of Applied Microbiology. 100. 219-232.

Janis, I., B. Kang and Flurkey, W.H. 1989. Tyrosinase Activity and lsoenzymes in Developing Mushrooms.Journal of Food Science. 54. 1. 
K. Ikehata and Nicell, J.A. 2000. Characterization of tyrosinase for the treatment of aqueous phenols. Bioresources Technology .74. 191199.

Khatun, S., A. Islam, U. Cakilcioglu and Chatterjee, C. 2012. Research on Mushroom as a Potential Source of Nutraceuticals: A Review on Indian Perspective American Journal of Experimental Agriculture. 2(1): 47-73.

Lowry, O.H. N.J. Rosenbrough, A.L. Forr and Randall, R.J. 1951. Protein measurement with Folin Phenol Reagent. Journal of Biological chemistry 193: 265-275.

Majidi, D., and Aksöz, N. 2013.Stability of Tyrosinase Enzyme from Funalia Trogii American Journal of Microbiological Research. 1. 1-3.

Manzi, P., L. Gambelli, S. Marconi, V. Vivanti and Pizzoferrato, L. 1999. Nutrient in edible mushroom an interspcies comparative study.Food Chemistry. 65. 477-82.

Masamba, K.G and Mwale, K.R. 2010.Determination and comparison of nutrient and mineral contents between cultivated and indigenous edible mushroom in central
Malawi.African Journal of Food Science.4(4).176-179.

Mata, G. and Salmones, D. 2003. Edible mushroom cultivation at the institute of ecology in Mexico.Micologia aplicada international.15 (1).23-29.

Ramkumar, L., T. Ramanathan and Nedumaran, T. 2011. In vitro effect of organic and inorganic additives from the production of radial mycelial growth and lignocellulolytic enzyme in Lentinus edodes. Emirates Journal of Food and Agriculture.23 (1): 71-79.

Royse, D.J. and Sanchez-Vazquez, J.E. 2003. Influence of precipitated calcium carbonate $(\mathrm{CaCO} 3)$ on shiitake (Lentinula edodes) yield and mushroom size. Bioresource Technology. 90. 225-228.

Xu, D.Y and Yang, Z. 2013. Cross-linked tyrosinase aggregates for elimination of phenolic compounds from wastewater. Chemosphere.92. 391398.

Zaidi,K. M., A. S. Ali, and Ali, S.A.2014. Purification and Characterization of Melanogenic Enzyme Tyrosinase from Button Mushroom.Enzyme research. 6 .

\section{How to cite this article:}

Anjana Sharma, Juhi Sharma and Pooja Thakrele. 2016. Screening, Localization and Activity of Mushroom Tyrosinase from Various Developmental Growth Phases of Pleurotus florida. Int.J.Curr.Microbiol.App.Sci. 5(1): 565-575. hittp://dx.doi.org/10.20546/ijcmas.2016.501.058 